\title{
3 次元結晶構造内部の变形と破壊の可視画像化
}

\author{
荻 原 律* 濱島 良 吉** 元 島 三 明** \\ Visualization of Internal Deformation and Fracture \\ of Three-Dimensional Crystal Structure
}

by

Tadashi OGihara ${ }^{*}$, Ryoukichi Hamajima ${ }^{* *}$ and Mitsuaki MotoJima ${ }^{* *}$

\begin{abstract}
Monitoring internal deformation and fracture of three-dimensional crystal structures under three-dimensional stress is very important. However, observing these phenomena solely by laboratory experiment is difficult. Several experimental results are available, but they are insufficient, since only the surfaces of the crystal structures could be observed. In an effort to obtain data beyond the limitations of laboratory experiment, we have been pursuing the development of computational simulation. This system enables us to analyze internal deformation and fracture of three-dimensional crystal structures with flaking and slipping on crystal grain boundaries. During this process we discovered the lack of useful visualization software, which is vital in evaluating the computational simulation results. In the present study we succeeded in developing visualization software which enables us to display and analyze internal deformation and fracture with flaking and slipping on crystal grain boundaries in an arbitrary cross section of three-dimensional crystal structures. The software development environment that we used is Direct3D "Retained Mode" in Microsoft DirectX7.
\end{abstract}

Key words : Visualization, Fracture, Crystal structure, Grain boundary, Finite element spring model

\section{1 緒}

\section{言}

本研究では, 3 主応力の作用を受ける岩石供試体のシ ミュレーションを行い，その内部の変形，破壊状態を把 握するための可視画像化手法を開発することを目的とし ている。解析に関しては，これまで不連続体解析 FESM (Finite element spring model) ${ }^{1) ~ 3)}$ を開発してきた。 この 解析手法は，困難とされてきた複雑な形状を有する 3 次 元結晶構造に対しての変形, 破壊を扱うものであり, 要 素内の弾性, 塑性, 粘弾性変形状態に加え, 結晶粒界で の引張破壊，せん断破壊によって生ずるはく離，滑りを 考虑することが可能な解析手法である。

複雑な多面体要素からなる結晶構造は, 分子動力学手 法と比較すればマクロな扱いとなり，設計に直結した分 野での適用が主体となる。しかし，現在，文部科学省で 進められている地球シミュレータプロジェクトでは並列 計算機抢よび有限要素法のプラグインソフト GeoFEM が 開発され，数千万個の要素の解析が可能となっている. またパソコンレベルでも数万個の要素の解析が可能であ り, ミクロな状態の解析が可能となりつつあり, 分子動 力学解析と結晶構造解析の距離が近づきつつあると思わ れる. この不連続体解析 FESM により，ミクロな結晶構 造解析加ら列島規模の地殸変動解析への応用も可能とな りつつある. 一方, アメリカ地質調查所 (USGS) に扔い ては 20 年以上前から円柱岩石供試体を用いて拘束圧, 間隙圧, 温度, 載荷速度を変化させた実験を行い, 地震
発生メカニズムに必要な岩石の構成則の一連の研究が行 われている。 さらに, 岩石内部の破壊を破壊音（アコー スティックエミッション) から把握し, これと荷重変形 曲線との対応の研究を行っている. しかし岩石内部の破 壊を把握するには必ずしも充分ではない.これに対し， 筆者らは三軸試験後の岩石供試体を薬品で固め, 断面を 細かくスライスし，この多数の断面写真から 3 次元画像

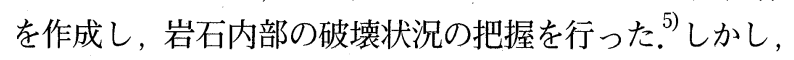
これには多大の労力を必要とするばかりでなく, 実験の 各変形段階での内部状態を把握することができない．こ うしたことを踏まえ, 結晶構造モデルによる破壊実験シ ミュレーション, 特に 3 主応力状態での解析の開発を行 ってきた。この場合, 供試体を任意の断面で切断し，そ こでの結晶構造のはく離, 滑りの状態を把握することが 必要となる。しかし, FESM 開発当初は, このように複 雑な 3 次元結晶構造内部の変形や破壊状態可視化可能 なソフトは残念ながら存在せず，すべて手作りで可視化 プログラムを開発してきた。現在では，6面体以内であ れば不連続体表現に対しても可視化可能なソフトが他に も存在する. しかし 6 面体を超える複雑な結晶構造にお いて任意の断面でスライスして, そこでの変形, 破壊状 態等を観察する可視化ソフトは自前でプログラム開発せ ざるを得ない. 本研究では, すべて手作りで可視化ソフ トを開発してきたが，こうした可視化ソフトの開発が逆に 結晶構造の研究に対する起爆戍となり得ると推察される.

$\dagger \quad$ 原稿受理 平成 14 年 6 月 11 日 Received June 11,2002

* 前橋工科大学工学研究科建設工学専攻 ₹371-0816 前橋市上佐鳥町, Dept. of Civil Eng., Maebashi Inst. of Tech., Kamisatori-cho, Maebashi, 371-0816

** 正 会 員 前橋工科大学工学部建設工学科 干371-0816 前橋市上佐鳥町, Dept. of Civil Eng., Maebashi Inst. of Tech., Kamisatori-cho, Maebashi, 371-0816 


\section{FESM (Finite Element Spring Model) の特徵}

本解析手法 FESM は, 以下に示す特徴を有する.

(1) 変位関数を要素重心の剛体変位と要素内の一定 ひずみで表すため, 要素形状の制約がなくなり，任意の 多面体要素を使用することができる，また，要素毎に変 形を独自に定めることができ，したがって，要素間での 相対変位を求めることが可能となり, 不連続体としての 解析が可能となる.

(2) 変位関数は 4 面体定ひずみ要素に対応するものと なっているため，4面体メッシュを用いた場合には，通 常の有限要素解と一致する.

(3) 弾塑性解析に扔いて, 要素内の弾塑性のみならず, 要素間での引張破壊，せん断破壊を扱うことができる.

\section{$2 \cdot 1$ FESM に基づく結晶構造要素内の变位の計算 と可視画像化に必要なデータ}

インプットデータとして，モデルを構成する要素（多 面体）の数と要素番号, 要素の頂点の数と頂点番号扣よ び頂点座標, そして要素を構成する面の数と面番号, 面 を構成する頂点の数と頂点番号が必要とされる。これら のデータより, 各要素重心点 $G$ の座標值 $\left(x_{G}, y_{G}, z_{G}\right)$ はプログラム内で要素の頂点座標から計算して得られる. また, 要素重心点の $x, y, z$ 方向の変位 $\left(u_{G}, v_{G}, w_{G}\right)$, $x, y, z$ 軸回りの回転角 $(\theta, \phi, \psi)$, 要素内の直ひずみ $\left(\varepsilon_{x}, \varepsilon_{y}, \varepsilon_{z}\right)$, そしてせん断ひずみ $\left(\gamma_{x y}, \gamma_{y z}, \gamma_{z x}\right)$ が解析 結果として得られる。これらより式 (1) を用いて, 要素 内の任意の点 $P(x, y, z)$ の $x, y, z$ 方向の変位 $u, v$, $w$ を求めることができる.これより各要素の頂点の変位 を求めることができる，ここで FESM では各要素が独立 に変位し得ることから, 要素間の引張破壊, 世ん断破壊 に基づく要素間の開口, 滑りを表現することができる. しかし, 隣り合う要素の頂点は, 接点番号を共有してい るため, 可視画像化に際しては, 同じ接点番号でも, 要 素每に独立した接点番号を設定し, 計算された変位を格 納して扔く必要がある。また要素内, 要素間の材料状態 をアウトプットしている．また要素間においては引張破 壊後の再接触, それに伴う材料の変化がアウトプットさ れる。

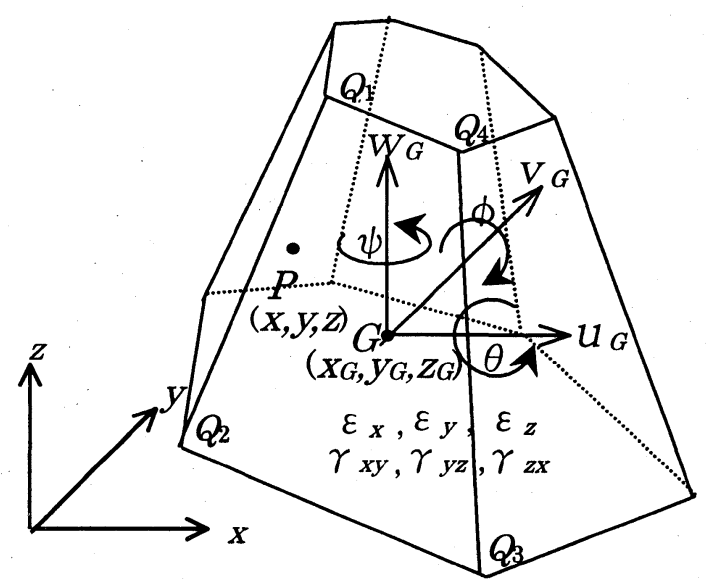

Fig. 1. Displacements and strains in crystal element.

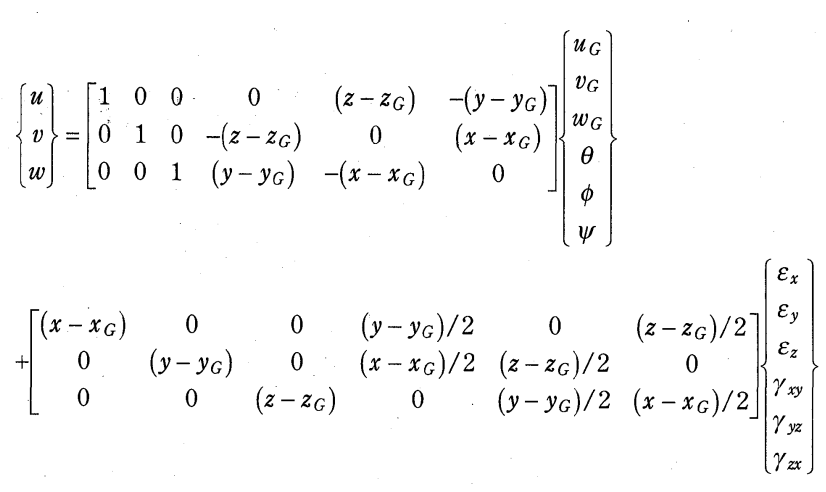

(1)

3 可視画像化プログラムの構成

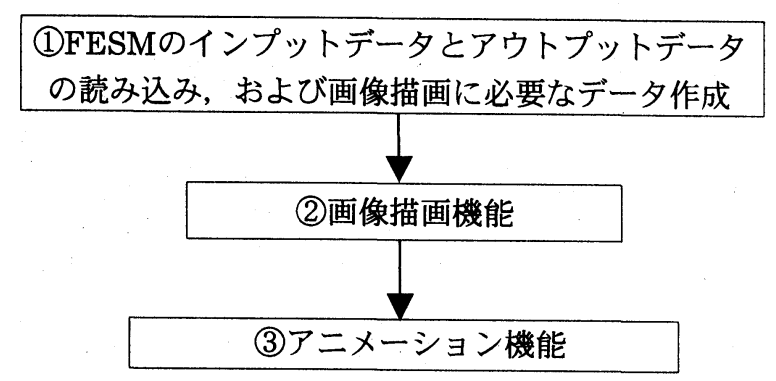

(1) データの読み込み・および画像描画に必要なデー タの作成

ここでは画像描画に必要なデータの入力, 作成を行う.

(1) 画像描画に必要なデータとしては, 先に述べたイ ンプットデータと FESM の解析により得られたアウトプ ットデータが必要となる。 これらより, 各要素の接点の 変位, さらに要素内の弹性, 塑性状態, 要素間の引張破 壊，せん断破壊の情報がインプットされる。これらのデ 一タから画像描画プログラムにより，(a) フラット表示, ワイヤーフレーム表示, (b) 破損面表示, 半透明表示, (c) 断面カット表示等が可能となる。これらは(2)の画像 描画機能を用いて比較的容易に可視画像化が可能である (第 4 章参照).

(2) 任意の断面で切断して, 厹の切断面での変形状 態，さらに破壊の状態を把握するために，切断面表示機 能が必要であり,ここで(2)の画像描画機能に必要なデー 夕を作成する。結晶構造に対してこうした機能を有する 可視化ソフトは無く, 可視画像化部分で最も苦労した. 結晶要素を平面で切断する場合には線と面との交点, 線 と面との接触, 面と面との接触を含めてプログラム上で の注意が必要となる (第 5 章参照).

(2) 画像描画機能

不連続体解析 FESM の開発当初はこうした可視画像化 に関するソフトは無く，すべてを手作りで行った。しか し現在では DirectX7 の機能の中の Direct3D-RM ${ }^{6)}$ の機能 を使うことにより，陰線处理，アニメーションを含めて 比較的容易に行うことができる（ただし DirectX8から は. Direct3D の RM（レジウムモード）の機能が無くな り手作りの必要がある)．画像描画をするための描画命令 は, AddVertex メソッド（頂点の追加機能）を用いて頂 点の座標值を指定する，次に, AddFaceメソッド（面の 
追加機能）を用いて各面を構成する頂点番号を指定する。 最捘に, Renderメリッドを用いて画像描画を行う.

(3) アニメーションプログラム

Visual Basicのタイマーコントロールを用いて，アニ メーションを作成する。ここではモデルを $x$ 軸， $y$ 軸，そ して $z$ 軸回りに回転させ, さらに, 同時に 2 軸以上の回 転をさせることもできるものとした。

\section{4 画像描画機能}

$4 \cdot 1$ フラット表示機能, ワイヤーフレーム機能

FESM 解析後の画像描画であるが，モデルの外形のみ で,モデル内部の状態を知ることはできない。

\section{$4 \cdot 2$ 破損面表示機能, 半透明表示機能}

Fig. 4 は不連続体解析 FESM 解析後のデータからの結 晶構造内部に生じた破損面の情報から，物体内部の破損 面を描画させた破損面表示機能である。これにより破壊 が生じた要素内部を視覚的に捉えることができる。ここ では, 要素内部の弾性, 塑性状態, 要素間での破壊の種 類を選択して表示可能である。

Fig. 5 はモデル全体に透過率を与え，モデル内部を透 視できるようにした半透明表示機能である。また，破損 面に色付けし，モデルを透視することによりモデル内部 のき裂や開口を，一層明膫に示すことができる。しかし 要素内部をより正確に把握するためには，断面をカット し，只こでの粒子の凹凸の状態を知ることが必要となる。 今後は数万個の要素での解析が可能となりつつ㐫り, 粒 子の大きさが破壞に及活す影響等を知る手掛りとなりう る $(4 \cdot 3$ 節参照 $)$.

\section{$4 \cdot 3$ 断面カット表示機能}

断面カット表示機能は, FESM の特徵である要素間の 栾形やはく離状態を知るために作成した機能であり，モ デル内部における個々の要素の形状を視覚的にとらえる ことができる．Fig． 6-aに示すモデルは解析後の状態で 西り，この断面カッ卜機能は現在 $x, y, z$ 軸に平行な任 意の面で要素を分断することができる。しかし，斜めの 任意断面でのカット機能についても, 比較的簡単に作成 可能であり，必要に応じて作成する。またカット面にお いて引張破壞, せん断破壊, さらには再接触等の変化も 表示可能であり，内部の破壞状態をより一層明らかにす

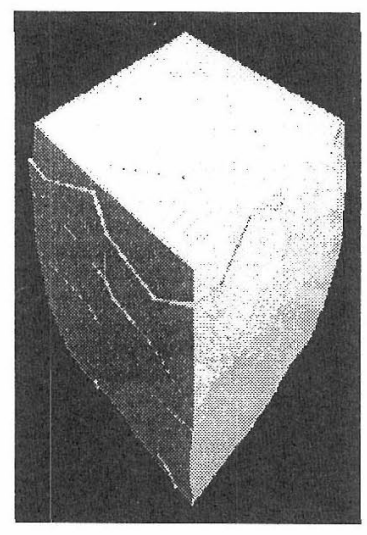

Fig. 2. Flat display.

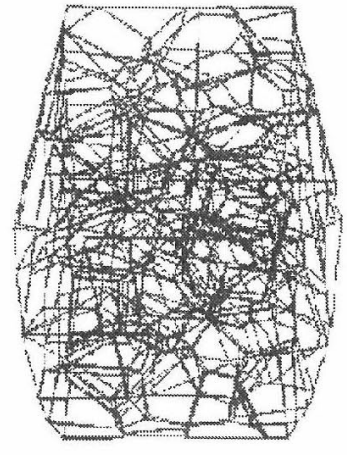

Fig. 3. Wire frame display.

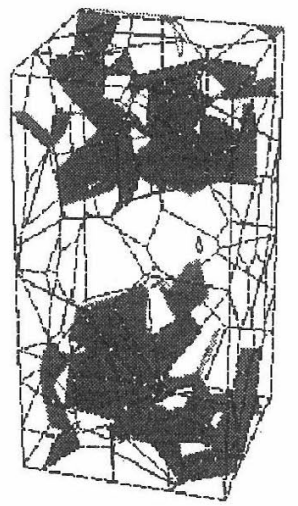

Fig. 4. Display of inner fracture surfaces.

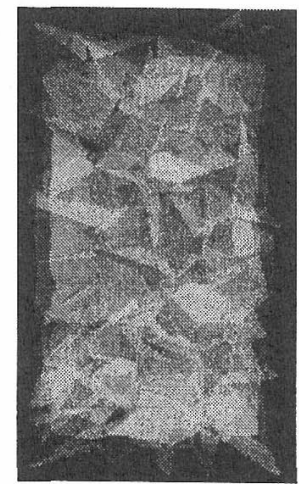

Fig. 5. Translucent display of model.
ることが可能となる。要素数の変化に伴う破壞性状の変 化と強度の変化との対応など多くの情報を得ることがで きよう。

\section{$4 \cdot 4$ 任意の位置を指定した切断面表示機能}

この機能はFESM の解析により得られた要素内部の変 形・破偯性状を知るために作成した機能である。これは モデルの亦ら汤る部分の切断面を取り出すことができ，兄 の切断面での要素内の弾塑性状態, 要素間の滑り, はく 離そして開口状態等を知ることができる(第 5 章参照)。

\section{5 任意の位置での結晶構造の切断}

モデルを任意の位置で切断する場合，切断する面を切 断面と定義する (Fig. 8 面 $P_{1} \sim P_{4}$ ). 方法としては, 3 次元べクトル表示により結晶構造と切断面との切断平面 （Fig. 9 面 $A_{1} \sim A_{6}$ ）を求めることになるが，基本的には 要素が構成する面の辺と切断面との交点を求めることに

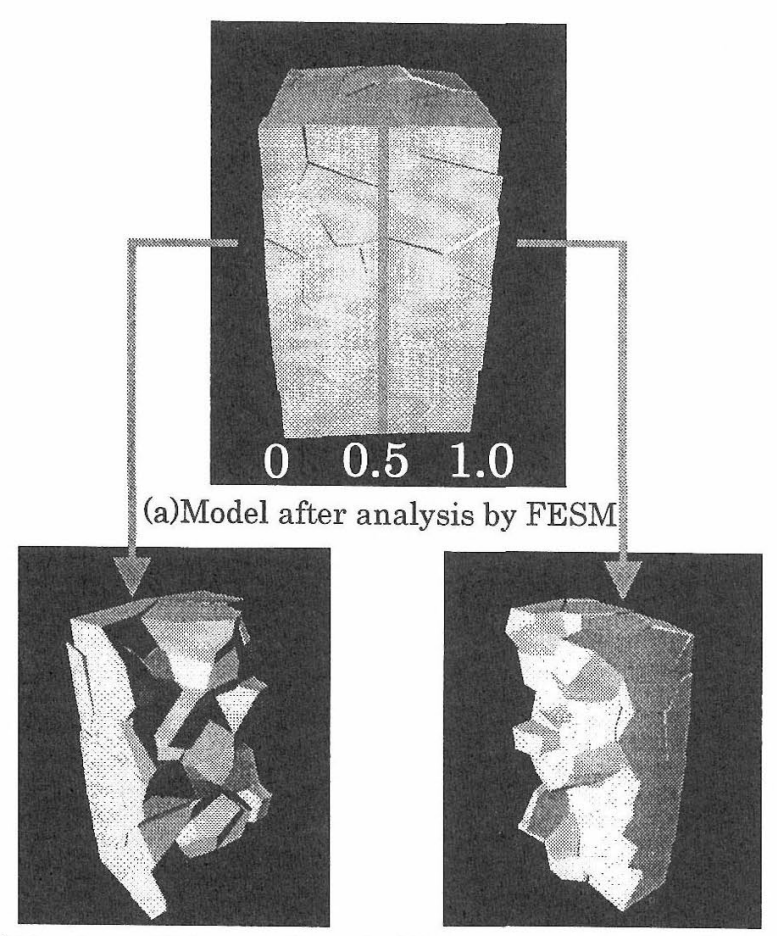

(b)Cutting-off domain(0-0.5). (c) Cutting-off domain(0.5-1.0). Fig. 6. Flaking display. 


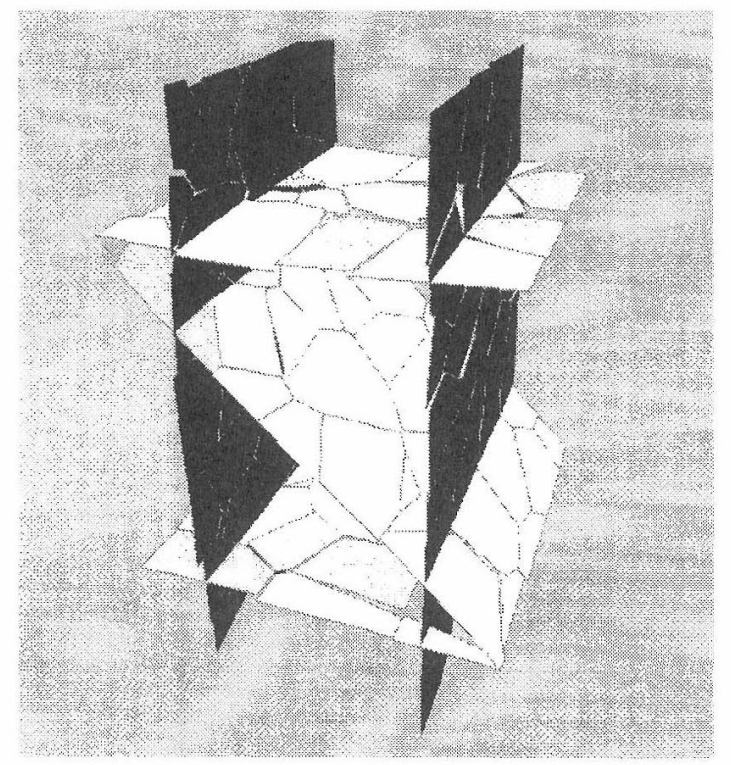

Fig. 7. Crystal structure cut by arbitrary cross sections.

帰着する。ただし, 要素の辺, さらに要素の面と切断面 との接触の判定等, 特殊な条件が発生する。

$5 \cdot 1$ 切断面表示機能のアルゴリズム

(1) Fig. 8 に示すように, モデル内に 3 点 $\left(P_{1}, P_{2}\right.$, $\left.P_{3}\right)$ を指定して切断する平面（切断面）を設定する。

(2) 切断面のベクトル方程式。

切断面の単位法線ベクトル $\boldsymbol{n}$ は, 方向ベクトル $\boldsymbol{A}$ (= $\left.\boldsymbol{P}_{2}-\boldsymbol{P}_{1}\right)$ と $\boldsymbol{B}\left(=\boldsymbol{P}_{3}-\boldsymbol{P}_{2}\right)$ より, 次式で与えられる。

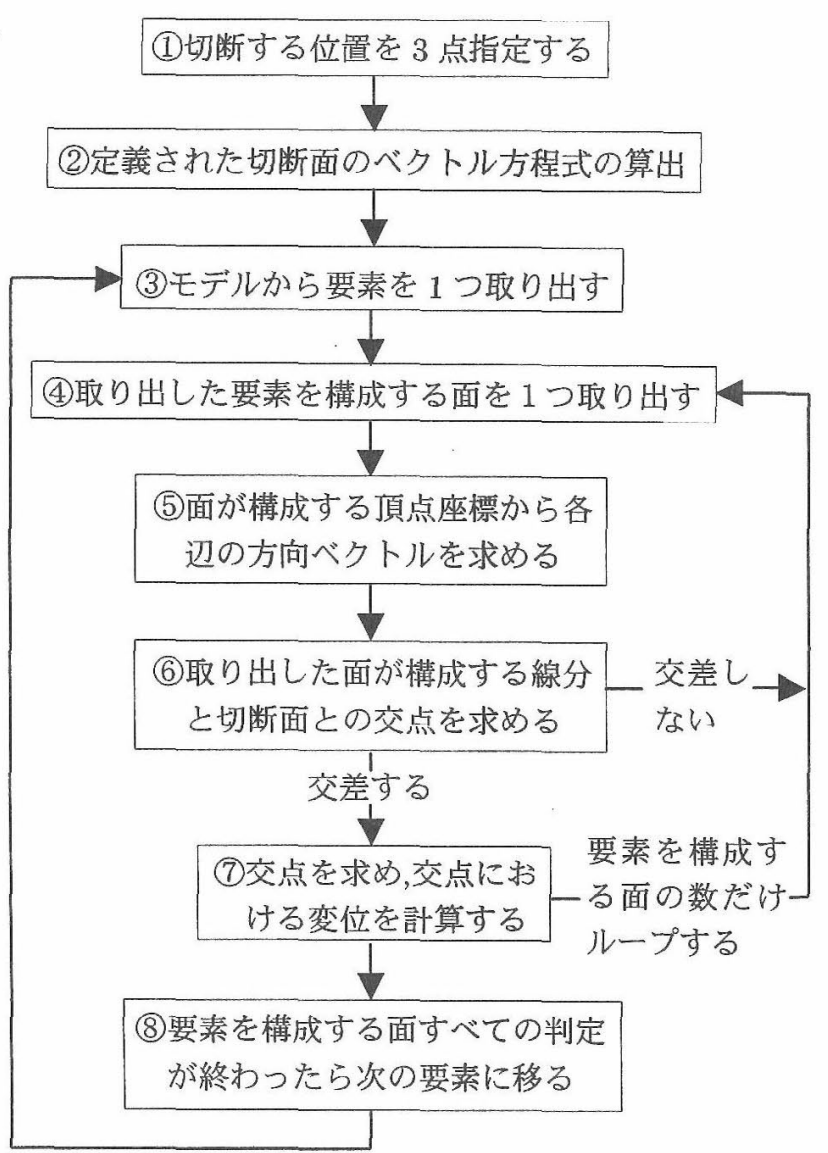

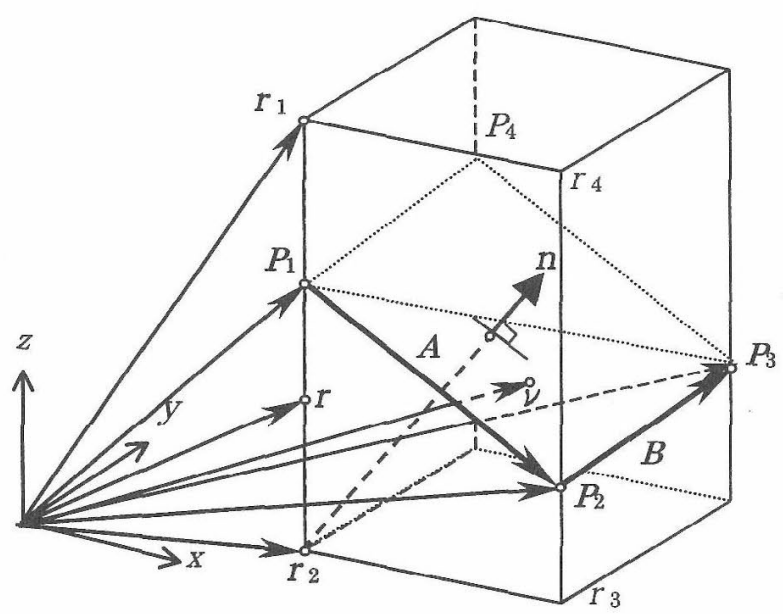

Fig. 8. Vector expression in crystal structure for a cross section.

$$
\boldsymbol{n}=\frac{\boldsymbol{A} \times \boldsymbol{B}}{\sqrt{(\boldsymbol{A} \times \boldsymbol{B}) \cdot(\boldsymbol{A} \times \boldsymbol{B})}}
$$

また，平面上の任意の点 $v$ における位置べタトル $v$ の法 線方向の成分を $k$ とすれば，次式の関係が成り立つ。

$$
\boldsymbol{n} \cdot \boldsymbol{v}=\boldsymbol{k}
$$

また, 点 $P_{1}$ の位置べタトルを $\boldsymbol{P}_{1}$ とすると, 式 (3) か ら $\boldsymbol{v}$ が $\boldsymbol{P}_{1}$ の位置にあるとき，次式が成り立つ。

$$
\boldsymbol{n} \cdot \boldsymbol{P}_{1}=\boldsymbol{k}
$$

これにより $k$ の值が定められる。式 (3) は点 $\left(P_{1}, P_{2}\right.$, $\left.P_{3}\right)$ から定めら妃る切断面のベタトル方程式である.

(3) Fig. 9 は，1 つの要素 (多面体) が切断面によっ て切断される面 $A_{1} \sim A_{6}$ 宗している。 これを得るため には要素を構成する面の各辺と切断面の交点を求めるこ とになる。この操作を，要素を構成するす心゙ての面につ いて行うことになる。

(4) ここでは，便亩的にFig. 9 に示卞要素の面 $Q_{1} Q_{2}$

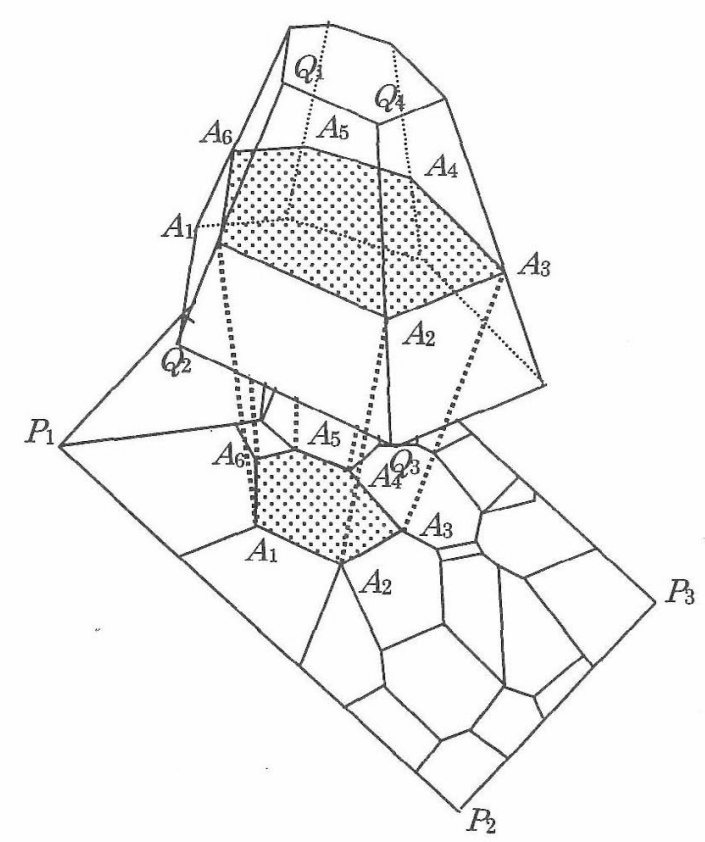

Fig. 9. Crystal element cut by a cross section. 
$Q_{3} Q_{4}$ を Fig. 8 に示したモデルの面 $r_{1} r_{2} r_{3} r_{4}$ に置きかえて 説明する。

(5) 直線 $r_{1} r_{2}$ 上に任意の点 $r$ を考えたときに，その点 に抢ける位置べクトル $\boldsymbol{r}$ は次式で得られる。

$$
\boldsymbol{r}=\boldsymbol{r}_{1}+\mu \boldsymbol{d}
$$

ただし, $\boldsymbol{d}=\boldsymbol{r}_{2}-\boldsymbol{r}_{1}$ であり, 直線の方向べクトルである.

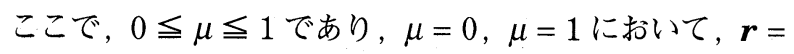
$\boldsymbol{r}_{1}, \boldsymbol{r}=\boldsymbol{r}_{2}$ となる.

(6) $\boldsymbol{r}=\boldsymbol{P}_{1}$ のとき, $\boldsymbol{r}=v$ とみなせるので式 (3) に式 （5）を代入すると, 次式となる.

$$
\boldsymbol{n} \cdot\left(\boldsymbol{r}_{1}+\mu \boldsymbol{d}\right)=k
$$

$\boldsymbol{n} \cdot \boldsymbol{d} \neq 0$ のとき（切断面と辺 $r_{1} r_{2}$ が平行でないとき）, 次の結果が得られる.

$$
\mu=\frac{k-\boldsymbol{n} \cdot \boldsymbol{r}_{1}}{\boldsymbol{n} \cdot \boldsymbol{d}}
$$

(7) $0 \leqq \mu \leqq 1$ の範囲においてのみ直線と切断面との 交点 $P_{1}$ の座標値を決定できる.

$$
\boldsymbol{P}_{1}=\boldsymbol{r}_{1}+\mu \boldsymbol{d}
$$

式 (8)から得られる座標值を式 (1) に代入することにより， 交点の変位を求めることができる.

(8)この处理を, 要素内のすべての面の辺について行 い，さらにモデル内のすべての要素について行う.

ただし, $\boldsymbol{n} \cdot \boldsymbol{d}=0$ の時, 単位法線ベクトルと直線の方向 ベクトルが直交するため, 面の辺と切断面は平行になる。 この場合にも交点を設定する場合があり，プログラム上 の注意事項で述べる.

\section{$5 \cdot 2$ プログラム上の注意}

\section{(1) $\boldsymbol{n} \cdot \boldsymbol{d}=\mathbf{0}$ における丸めの誤差}

切断面表示のプログラムにおいて, 直線 (辺) の方向 ベクトル $\boldsymbol{d}$ を求めるときに必要な変数は single（単精度 浮動小数点型）で変数の宣言をしている. single は, 有 効けた数約 7 けたなので, 1.23456789 という 9 けたの数 字を内部的にその值を丸めて 1.234567 にする. このよう な内部処理が行われることによって誤差が生じる．この ため, 平面と直線が平行のとき $\boldsymbol{n} \cdot \boldsymbol{d}=0$ となるはずが, 丸め誤差のために $\boldsymbol{n} \cdot \boldsymbol{d}=0$ とならなくなる恐れがある. そこで, プログラム上では近似的に

$$
|\boldsymbol{n} \cdot \boldsymbol{d}|<0.000001
$$

において $\boldsymbol{n} \cdot \boldsymbol{d}=0$ が成り立つとする.

\section{(2) 要素 (多面体) を切断する平面と要素との関係}

Fig. 10 (a) 〜(f) に打いて面 $Q_{1} Q_{2} Q_{3} Q_{4}$ と切断面との交 点について分類する.

(a) 面上で 2 つの交点を有する場合

面上に打いて, 式 (7) を用い, $\mu$ の值が次式で得られ

る.また $\mu$ は $0 \leqq \mu \leqq 1$ である.

交点の位置べクトルは次式から求められる.

$$
\left.\begin{array}{l}
\boldsymbol{A}_{1}=\boldsymbol{Q}_{1}+\mu\left(\boldsymbol{Q}_{2}-\boldsymbol{Q}_{1}\right) \\
\boldsymbol{A}_{2}=\boldsymbol{Q}_{3}+\mu\left(\boldsymbol{Q}_{4}-\boldsymbol{Q}_{3}\right)
\end{array}\right\}
$$

(b) 面上で切断面と $2 つ の$ 交点を有するが, 面の頂点 に交点を有する場合

(a) の手順を進める中で, 交点が面の頂点と一致する 場合がある. 例えば，Fig. 10 (b) に抢いて直線 $Q_{1} Q_{2}$,
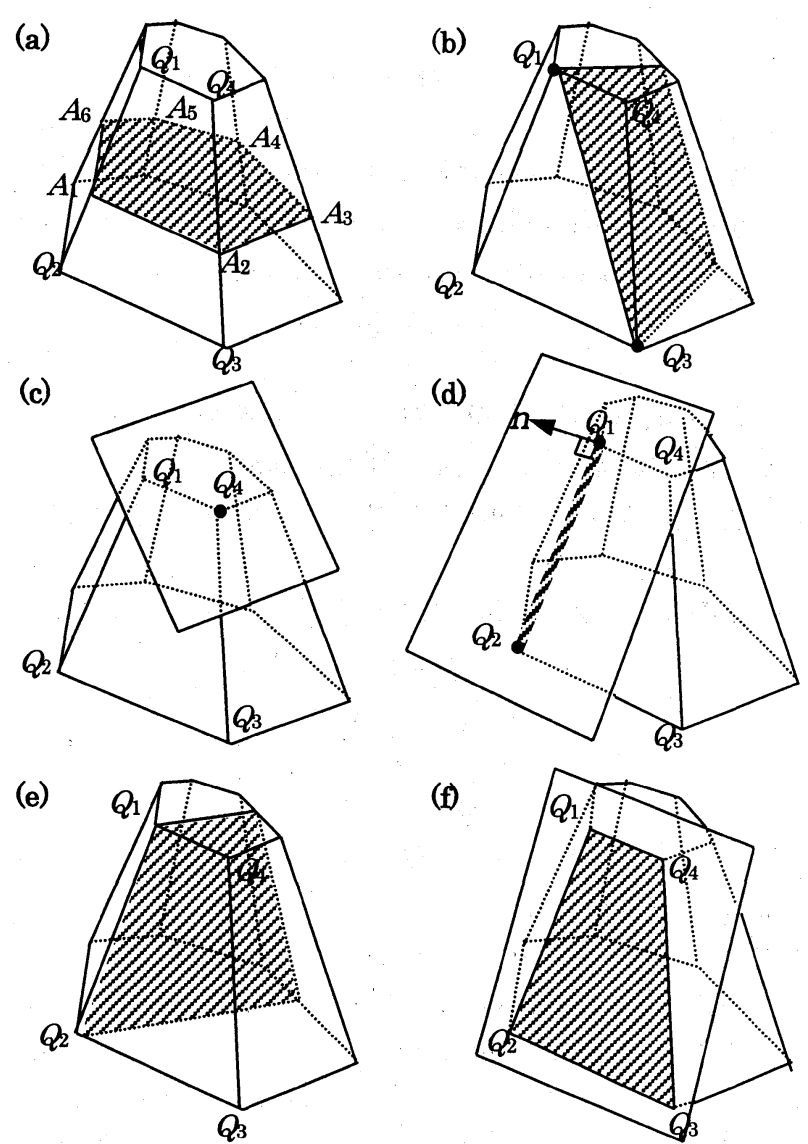

Fig. 10. Crystal element cut by a cross section.

$Q_{2} Q_{3}$, そして $Q_{3} Q_{4}$ と切断面との交点の位置が，それぞ れ $\mu=0, \mu=1, \mu=0$, そして $\mu=1$ となっている.この

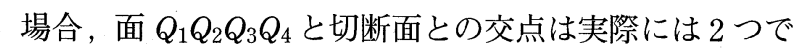
あるが見かけ上 4 つあことになる。これに対しプログ ラム上では, $\mu=0$ の場合は, 直線と平面が交わってい るとみなし, $\mu=1$ の場合は, 交わっていないとする. すなわち， $0 \leqq \mu<1$ とする．こうすることで，平面は 直線 $Q_{1} Q_{2}$ と $Q_{3} Q_{4}$ の 2 箇所で交わっていることになり, 交点は 2 つとなる。 これは (a) における特殊な場合とし て扱うことができる

交点の位置べクトルは式 (10) において,

辺 $Q_{1} Q_{2}$ において $\mu=0, \boldsymbol{A}_{1}=\boldsymbol{Q}_{1}$

辺 $Q_{3} Q_{4}$ において $\left.\mu=0, \boldsymbol{A}_{2}=\boldsymbol{Q}_{3}\right\}$

(c) 要素を構成する面の頂点が切断面と 1 箇所で接す る場合

これは，(b) の特殊な場合であり，要素を構成する面 上において $\mu=0$ が 1 つのみ生ずる場合（ここでは $Q_{4}$ ） である。この場合, 要素は切断される面を持たない. そ のため, この場合の交点は除外しておく必要がある.

(d) 要素の面を構成する辺の 1 つのみが切断面上にあ る場合

切断面の単位法線ベクトル $\boldsymbol{n}$ と方向ベクトル $\boldsymbol{Q}_{1} \boldsymbol{Q}_{2}$ が 直行することから，

$$
\boldsymbol{n} \cdot\left(\boldsymbol{Q}_{2}-\boldsymbol{Q}_{1}\right)=0
$$

更に次式が成り立てば切断面上に点 $Q_{1}$ および $Q_{2}$ が存在 する。 


$$
\begin{aligned}
& \boldsymbol{n} \cdot \boldsymbol{Q}_{1}-k=0 \\
& \left(\boldsymbol{n} \cdot \boldsymbol{Q}_{2}-k=0\right. \text { でも良い) }
\end{aligned}
$$

式 (12)，(13）において, 式 (9) の近似を行う。この場合 には，点 $Q_{1}, Q_{2}$ の座標值を交点として記録する.

(e) 要素の面を構成する辺の 1 つが切断面上にある場合 この場合は 1 つの辺上で (d) と同じ条件が成立する.

$$
\left.\begin{array}{r}
\boldsymbol{n} \cdot\left(\boldsymbol{Q}_{2}-\boldsymbol{Q}_{1}\right)=0 \\
\boldsymbol{n} \cdot \boldsymbol{Q}_{1}-k=0
\end{array}\right\}
$$

この場合には, 点 $Q_{1}, Q_{2}$ の座標值を交点として記録 し，あとは (a) の場合と同じ手順を進める.

(f) 要素の 1 つの面上において 2 うの辺が切断面上に ある場合

この場合は 2 つの辺上で (d) と同じ条件が成立する.

$$
\begin{aligned}
& \boldsymbol{n} \cdot\left(\boldsymbol{Q}_{2}-\boldsymbol{Q}_{1}\right)=0 \\
& \boldsymbol{n} \cdot \boldsymbol{Q}_{1}-k=0 \\
& \boldsymbol{n} \cdot\left(\boldsymbol{Q}_{4}-\boldsymbol{Q}_{3}\right)=0 \\
& \boldsymbol{n} \cdot \boldsymbol{Q}_{4}-k=0
\end{aligned}
$$

この場合には，点 $Q_{1}, Q_{2}, Q_{3}, Q_{4}$ の座標値のみを交 点として記録する。

\section{6 結}

言

不連続体解析 FESM は多面体としてのボロノイ分割要 素を用いることが可能である，要素の変形を考慮でき， さらに要素間の引張破壊, せん断破壊を考慮できる. 変 形は要素重心点の剛体変位と要素内の定ひずみで表され る。このことから, 個々の要素が独立して運動し, かつ 要素形状には拘束されない（ただしここでは 12 面体ま でのボロノイ分割要素を用いている)。これまで岩石実験 の内部の破壊性状を把握することが困難であったが FESM の解析と併用して本研究で行った可視画像化が有 効となる。

可視画像化においては DirectX7 のサブシステムである Direct3D を用いた。これは DirectX7 以降 Visual Basic でグラフィックス・ライブラリを読み込むことが可能と なり，画像処理の専門知識があまり無くても陰線処理な どの基本的 3 次元グラフィックス機能を活用することが
可能である. 画像描画のためのデータとして, 要素 (多 面体）の数と要素番号, 要素の接点数と接点番号および 接点座標（変位を加算したもの）, 要素を構成する面の 数と面番号, その面の頂点数と頂点番号が必要とされる. さらに要素内の弾性, 塑性状態, 要素間の引張破壊, せ ん断破壊の情報が必要となる. FESM では結晶要素毎に これらのデータを与えることができる。ただし任意の断 面で切断される切断面上（2次元平面上）での画像表示 に関しては，Direct3D に受け渡す情報（切断される多面 体から形成される 2 次元多角形）を作成し，これに基づ いて可視画像化を行った. 結晶構造に対してこうした機 能を有する可視化ソフトは無く, 可視画像化部分で最も 苦労した. 結晶要素を平面で切断する場合には線と面と の交点, 線と面との接触, 面と面との接触を含めてプロ グラム上での注意が必要となる。 画像描画の主な機能としては

(a) フラット表示, ワイヤーフレーム表示,

(b) 破損面表示，半透明表示，

(c) 断面カット表示,

(d) 任意の断面で切断し, その切断面での変形状態表 示等が可能であるが, 状況に応じて機能が追加される.

\section{参 考 文 献}

1) 中井仁彦, 濱島良吉, 日本地熱学会誌, 16, No.4, 1 (1995).

2) 中井仁彦, 濱島良吉, 日本地熱学会誌, 17, No.2, 95 (1995).

3 ) 濱島良吉, 元島三明, 第 7 回分子動力学シンポジウム講演 論文集, 77 (2002).

4 ）濱島良吉, 元島三明, 第 7 回分子動力学シンポジウム講演 論文集，82(2002).

5 ) 清水 均, 高橋 学, 濱島良吉, 応用地質, 36, No.3, 265 (1995).

6) 川田 徹, “Visual Basic による Direct3D アニメーション 入門”, 第 1 章 (1999) 工学社. 